\title{
Spongia (Heterofibria) sucrensis sp. nov. (Dyctioceratida: Spongiidae): una nueva especie de esponja para el Caribe colombiano
}

\section{Spongia (Heterofibria) sucrensis sp. nov. (Dyctioceratida: Spongiidae): a new sponge species from the Colombian Caribbean}

\author{
Jesús David-Colón* y Dairo Marín-Casas \\ $\begin{array}{ll}\text { (iD) } 0000-0001-7973-6210 & \text { (iD) } 0000-0002-0372-9847\end{array}$ \\ 1. Grupo de investigación Biología Evolutiva, programa de Biología, Universidad de Sucre, Sincelejo, Colombia. jesusdanieldavid@gmail.com*, dairo. \\ marin@unisucre.edu.co \\ * Autor de correspondencia.
}

\section{RESUMEN}

$\mathrm{S}$ e describe la nueva especie Spongia (Heterofibria) sucrensis sp. nov. que fue recolectada en rompeolas del municipio de Coveñas, departamento de Sucre (Caribe colombiano). Esta es una esponja masiva, con lóbulos o ramas erectas y rastreras; esqueleto de fibras primarias ascendentes con inclusiones de material foráneo; mallas de fibras secundarias y pseudoterciarias sin inclusiones dominan el esqueleto; fibras pseudoterciarias más claras y conectadas a los otros tipos de fibras o formando un retículo dentro de mallas de fibras secundarias. Este hallazgo constituye el primer registro y descripción de una especie del subgénero Heterofibria para Colombia y el Caribe, lo que eleva a nueve las especies del género para el Caribe y a tres para Colombia.

PALABRAS CLAVE: Caribe, Spongia (Heterofibria), especie nueva, Spongiidae, Porifera

\section{ABSTRACT}

$\mathrm{T}$ The new species Spongia (Heterofibria) sucrensis sp. nov, that was collected in breakwaters in the municipality of Coveñas, department of Sucre (Colombian Caribbean) is described. This is a massive sponge, with erect and creeping lobes or branches; skeleton of ascending primary fibers cored with foreign material; secondary and pseudotertiary fiber meshes cored dominate the skeleton; lighter pseudotertiary fibers connected to the other fiber types or forming a reticulum within secondary fibers meshes. This finding constitutes the first record and description of a species of the subgenus Heterofibria for Colombia and the Caribbean, which raises to nine the species number of the genus for the Caribbean and three for Colombia.

KEYWORDS: Caribbean, Spongia (Heterofibria), new species, Spongiidae, Porifera

DOI: https://doi.org/10.25268/bimc.invemar.2020.49.2.976 Publicado por INVEMAR 


\section{INTRODUCCIÓN}

En la familia Spongiidae se incluyen esponjas que se usan comercialmente para el baño y el lavado. Estas se caracterizan por poseer un esqueleto de fibras de espongina homogéneas, sin laminaciones distintivas, generalmente dominado por una red de fibras subprimarias, y también por tener cámaras de coanocitos diploidales. Esta familia consta de seis géneros válidos, uno de los cuales, Spongia Linnaeus, 1759, incluye tres subgéneros: Spongia, Heterofibria Cook y Bergquist, 2001 y Australospongia Cook y Bergquist, 2001 (Cook y Bergquist, 2001). Especies del género Spongia poseen una superficie de cónulos bajos dispuestos uniformemente. La consistencia es elástica, flexible y muy compresible. El retículo esquelético está compuesto de un reducido número de fibras primarias ascendentes con inclusiones de material foráneo y de un retículo secundario de fibras sin inclusiones, altamente desarrollado (Cook y Bergquist, 2002). Spongia contiene 65 especies válidas descritas, de las cuales 8 se encuentran en el Caribe (Van Soest et al., 2019).

El subgénero Heterofibria se distingue de los otros dos subgéneros por tener una dicotomía distintiva de tamaño entre las fibras del esqueleto secundario. Las fibras de mayor diámetro son denominadas secundarias y las de menor diámetro pseudoterciarias, lo que genera un retículo subprimario (Cook y Bergquist, 2001). Las primeras especies descritas del subgénero Heterofibria fueron $S$. corrugata Cook y Bergquist, 2001, S. decooki Van Soest \& Hooper, 2020 (misma que Spongia (Heterofibria) cristata Cook y Bergquist, 2001), S. gorgonocephalus Cook y Bergquist, 2001, S. manipulatus Cook y Bergquist, 2001 y S. mokohinau Cook y Bergquist, 2001 en Nueva Zelanda, a partir de una revisión del género Spongia (Cook y Bergquist, 2001). Este subgénero se ve representado en el Atlántico de Brasil por S. catarinensis Mothes, Kasper, Lerner, Campos y Carraro, 2006. Kim y Sim (2009) describieron dos especies de las costas de Corea: S. corallina y S. purpurea. Samaai et al. (2019) describieron S. cooki (nombre que fue remplazado por S. peddemorsi Samaai, Pillay y Janson, 2020) y S. smaragdus de Sodwana Bay, en la costa oriental de Sudáfrica.

Para Colombia, dos especies de Spongia han sido registradas y descritas por Zea (1987): S. (Spongia) tubulifera Lamarck, 1814 y S. (Spongia) anclotea De Laubenfels y Storr, 1958 (como $S$. obscura Hyatt, 1877 y $S$. pertusa Hyatt, 1877 respectivamente). En el presente estudio se describe una nueva especie de Spongia (Heterofibria)

\section{INTRODUCTION}

The Spongiidae family includes sponges that are used commercially for bathing and washing. These are characterized by having a skeleton of homogeneous spongin fibers, without distinctive laminations, generally dominated by a network of sub-primary fibers, and also by having diplodal choanocytes chambers. This family consists of six valid genera, one of which, Spongia Linnaeus, 1759, includes three subgenera: Spongia, Heterofibria Cook, and Bergquist, 2001 and Australospongia Cook and Bergquist, 2001 (Cook and Bergquist, 2001). Species of the genus Spongia possess a surface of uniformly arranged low conules. The consistency is elastic, flexible, and very compressible. The skeletal reticulum is composed of a small number of ascending primary fibers cored with foreign material and a highly developed uncored secondary reticulum (Cook and Bergquist, 2002). Spongia contains 65 valid described species, of which 8 are found in the Caribbean (Van Soest et al., 2019).

The subgenus Heterofibria is distinguished from the other two subgenera by having a distinctive size dichotomy between the fibers of the secondary skeleton. Fibers with a larger diameter are called secondary and those with a smaller diameter pseudo-tertiary, which generates a sub-primary reticulum (Cook and Bergquist, 2001). The first species of the subgenus Heterofibria described were $S$. corrugata Cook and Bergquist, 2001, S. decooki Van Soest and Hooper, 2020 (same as Spongia (Heterofibria) cristata Cook and Bergquist, 2001), S. gorgonocephalus Cook and Bergquist, 2001, S. manipulatus Cook and Bergquist, 2001 and S. mokohinau Cook and Bergquist, 2001 in New Zealand, based on a review of the genus Spongia (Cook and Bergquist, 2001). This subgenus is represented in the Brazilian Atlantic by $S$. catarinensis Mothes, Kasper, Lerner, Campos, and Carraro, 2006. Kim and Sim (2009) described two species from the coasts of Korea: S. corallina and S. purpurea. Samaai et al. (2019) described S. cooki (a name that was replaced by S. peddemorsi Samaai, Pillay and Janson, 2020) and S. smaragdus from Sodwana Bay, on the east coast of South Africa.

For Colombia, two species of Spongia have been recorded and described by Zea (1987): S. (Spongia) tubulifera Lamarck, 1814 and S. (Spongia) anclotea De Laubenfels and Storr, 1958 (as S. obscura Hyatt, 1877 and S. pertusa Hyatt, 1877 , respectively). This study describes a new species of Spongia (Heterofibria) collected in 
recolectada en rompeolas de las playas del departamento de Sucre (Caribe colombiano).

\section{ÁREA DE ESTUDIO}

Este estudio se realizó en dos rompeolas de roca calcárea ubicados en las playas Boca La Caimanera $\left(9^{\circ} 26^{\prime} 6,33^{\prime \prime}-21,46^{\prime \prime}\right.$ N $\left., 75^{\circ} 37^{\prime} 40,39^{\prime \prime}-52,15^{\prime \prime}\right)$ y punta Piedra $\left(9^{\circ} 25^{\prime} 21,62^{\prime \prime} \mathrm{N}, 75^{\circ} 39^{\prime} 5,31^{\prime \prime}\right.$ O) en el municipio de Coveñas, departamento de Sucre (Colombia), parte sur del golfo de Morrosquillo (Figura 1). Los rompeolas están ubicados a ambos costados de la desembocadura de la laguna costera La Caimanera, a una distancia máxima de $116 \mathrm{~m}$ de la costa y a una profundidad menor de $3 \mathrm{~m}$. Los rompeolas están breakwaters from the beaches of the department of Sucre (Colombian Caribbean).

\section{STUDY AREA}

This study was carried out in two calcareous rock breakwaters located on the Boca La Caimanera beaches $\left(9^{\circ} 26^{\prime} 6.33^{\prime \prime}-21.46^{\prime \prime} \mathrm{N}, 75^{\circ} 37^{\prime} 40.39^{\prime \prime}-52.12^{\prime \prime}\right)$ and Punta Piedra $\left(9^{\circ} 25^{\prime} 21.62^{\prime \prime} \mathrm{N}, 75^{\circ} 39^{\prime} 5.31^{\prime \prime} \mathrm{W}\right)$ in the municipality of Coveñas, department of Sucre (Colombia), the southern part of the Gulf of Morrosquillo (Figure 1). The breakwaters are located on both sides of the mouth of the coastal lagoon La Caimanera, at a maximum distance of $116 \mathrm{~m}$ from the coast and at a depth of less than $3 \mathrm{~m}$. Breakwaters are

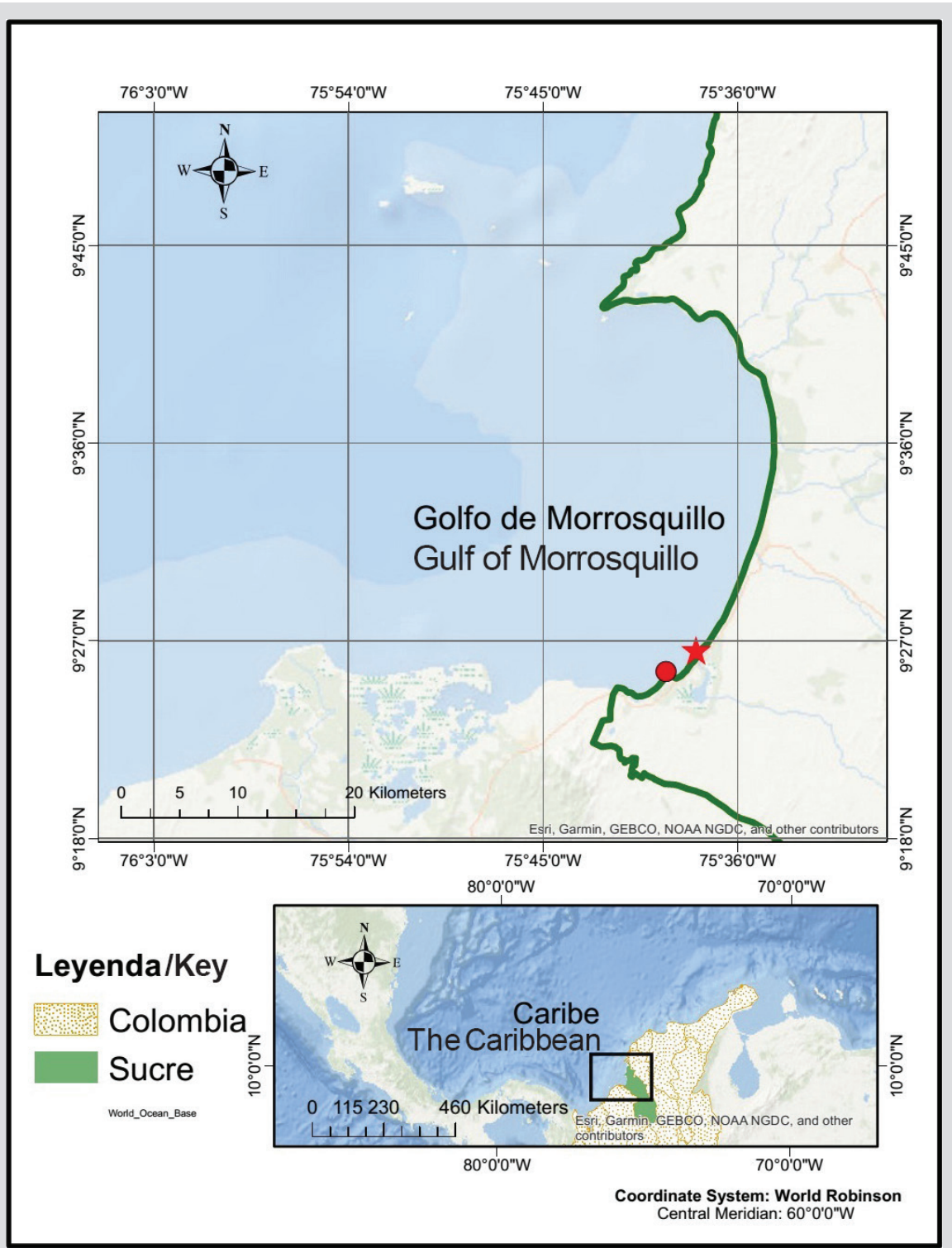

Figura 1. Área de estudio. ^ Playas Boca La Caimanera. • Punta Piedra.

Figure 1. Study area. $\star$ Boca La Caimanera beaches. $\bullet$ Punta Piedra. 
acompañados por praderas de pastos marinos en los que habitan moluscos, equinodermos y poríferos. Punta Piedra es un bajo coralino compuesto principalmente por las especies Millepora complanata Lamarck, M. squarrosa Lamarck, Siderastrea siderea (Ellis y Solander) y Siderastrea radians (Pallas); se encuentra deteriorado y es abundante el coral muerto. La altura de las olas es inferior a la que se presenta en otras partes del Caribe colombiano y los eventos extremos del oleaje son generados principalmente por frentes fríos (Otero et al., 2016).

\section{MATERIALES Y MÉTODOS}

Los especímenes fueron recolectados entre el 20 de agosto de 2017 y el 22 de junio de 2018 mediante buceo a pulmón libre, de forma manual usando una espátula, y se depositaron en una bolsa resellable que contenía agua de mar. También se tomaron fotografías en el lugar con una cámara SJ4000 de SJCAM a $12 \mathrm{mp}$. Las muestras fueron fijadas y etiquetadas en frascos de vidrio con etanol al $70 \%$ para su posterior identificación taxonómica y, luego, fueron depositadas en el Museo de Zoología de la Universidad de Sucre (MZUSU).

La identificación de las esponjas se realizó a través de cortes histológicos gruesos según la metodología de Zea (1987). Se utilizaron las claves taxonómicas propuestas por Hooper y Van Soest (2002b) y el trabajo de Mothes et al. (2006) hasta llegar al nivel de subgénero. También se hicieron comparaciones con muestras de las especies $S$. anclotea, $S$. tubulifera e Hyatella cavernosa (Pallas, 1766) para llegar hasta el nivel de especie. Las fotografías de la arquitectura del esqueleto fueron tomadas con un microscopio Labomed equipado con cámara iVu 3100. Las mediciones de las fibras y la distancia entre estas se calcularon con el programa PixelPro versión 2,8, a partir de la calibración del software con micrómetro de platina. Las medidas se presentan como mínimo-promedio-máximo. Por su parte, las mediciones de los ósculos, los lóbulos y el tamaño del fragmento se calcularon con un calibrador electrónico.

\section{RESULTADOS}

Taxonomía

Clase Demospongiae Sollas, 1885

Orden Dictyoceratida Minchin, 1900

Familia Spongiidae Gray, 1867

Género Spongia Linnaeus, 1759 accompanied by seagrass meadows inhabited by mollusks, echinoderms, and porifers. Punta Piedra is a coral reef composed mainly of the species Millepora complanata Lamarck, M. squarrosa Lamarck, Siderastrea siderea (Ellis and Solander), and Siderastrea radians (Pallas); it is deteriorated and dead coral is abundant. The wave height is lower than that found in other parts of the Colombian Caribbean and extreme wave events are generated mainly by cold fronts (Otero et al., 2016).

\section{MATERIALS AND METHODS}

The specimens were collected between August 20, 2017 and June 22, 2018 by free diving, manually using a spatula, and placed in a resealable bag containing seawater. Photographs were also taken on-site with an SJCAM SJ4000 camera at $12 \mathrm{mp}$. The samples were fixed and labeled in glass jars with $70 \%$ ethanol for subsequent taxonomic identification and, later, they were deposited in the Museum of Zoology of the University of Sucre (MZUSU).

The identification of the sponges was carried out through thick histological sections according to the methodology of Zea (1987). The taxonomic keys proposed by Hooper and Van Soest (2002b) and the work of Mothes et al. (2006) up to the subgenus level. Comparisons were also made with samples of the species S. anclotea, S. tubulifera and Hyatella cavernosa (Pallas, 1766) to arrive at the species level. The photographs of the skeleton architecture were taken with a Labomed microscope equipped with an iVu 3100 camera. The measurements of the fibers and the distance between them were calculated with the PixelPro version 2.8 program, from the calibration of the software with a micrometer of the platen. Measurements are presented as minimumaverage-maximum. On the other hand, the measurements of the oscula, the lobes, and the size of the fragment were calculated with an electronic caliper.

\section{RESULTS}

\section{Taxonomy}

Class Demospongiae Sollas, 1885

Order Dictyoceratida Minchin, 1900

Family Spongiidae Gray, 1867

Genera Spongia Linnaeus, 1759 
Diagnosis (de Cook y Bergquist, 2001): esponjas suaves a firmes y compresibles. Con un retículo esquelético de fibras primarias, con inclusiones de material foráneo y fibras secundarias $\sin$ inclusiones; fibras primarias más evidentes cerca de la superficie, donde pueden atravesar la dermis. Los cónulos, cuando se encuentran presentes, están sostenidos por uno o varios mechones de fibras primarias emergentes. Esqueleto dominado por una malla de fibras secundarias sin inclusiones, lo que da a estas esponjas su flexibilidad y sus propiedades de retención de agua. Estas mallas se crean por la intersección y unión de fibras, y cada intersección de fibra siempre con tres fibras que se alejan de ella.

Subgénero Heterofibria Cook y Bergquist, 2001

Diagnosis (de Cook y Bergquist, 2001): esqueleto dominado por retículos de fibras subprimarias, de las cuales las de mayor diámetro son denominadas fibras secundarias y las de menor diámetro fibras pseudoterciarias. Mallas formadas por esqueleto de fibras, usualmente poligonales, aunque irregulares en tamaño y forma, menos angulares que las del subgénero Spongia, como se caracteriza para $S$. officinalis.

Spongia (Heterofibria) sucrensis sp. nov. (Figura 2)

Material tipo: Holotipo. MZUSU-I00005: boca La Caimanera, rompeolas, 1-3 m, 20-agosto-2017, col. J. David; Paratipos: MZUSU-I00026: Punta Piedra, arrecife coralino, 2-4 m, 22-junio-2018, col. J. David; MZUSU-I00027: boca La Caimanera, rompeolas, 1-3 m, 20-agosto-2017, col. J. David; MZUSU-I00028: Punta Piedra, arrecife coralino, 2-4 m, 22-junio-2018, col. J. David.

Material adicional para comparación: Spongia (Spongia) tubulifera (MZUSU-I00014); Hyattella cavernosa (MZUSU-I00040); S. (Spongia) anclotea (MZUSU-I00036).

Diagnosis: esponja masiva, con lóbulos o ramas erectas y rastreras. Esqueleto de fibras primarias ascendentes con inclusiones de material foráneo. Mallas de fibras secundarias y pseudoterciarias sin inclusiones dominan el esqueleto. Fibras pseudoterciarias más claras conectadas a los otros tipos de fibras o formando un retículo dentro de mallas de fibras secundarias.

Morfología externa: esponja masiva con lóbulos erectos y rastreros de longitud máxima de $5 \mathrm{~cm}$ y de ancho máximo de $1,7 \mathrm{~cm}$. Ósculos redondos como perforaciones del pinacodermo, 1-3 mm de diámetro, ubicados principalmente en la parte superior de los lóbulos y dispuestos linealmente
Diagnosis (from Cook and Bergquist, 2001): soft to firm and compressible sponges. With a skeletal network of primary fibers, cored with foreign material and uncored secondary fibers; more obvious primary fibers near the surface, where they can pass through the dermis. Conules, when present, are supported by one or more tufts of emerging primary fibers. Skeleton is dominated by a mesh of uncored secondary fibers, which gives these sponges their flexibility and their water retention properties. These meshes are created by the intersection and union of fibers, and each fiber intersection always has three fibers moving away from it.

Subgenus Heterofibria Cook and Bergquist, 2001

Diagnosis (from Cook and Bergquist, 2001): skeleton dominated by networks of sub-primary fibers, of which the larger diameter fibers are called secondary fibers and the smaller diameter fibers pseudo-tertiary. Meshes formed by skeleton fibers, usually polygonal, although irregular in size and shape, less angular than those of the subgenus Spongia, as characterized in S. officinalis.

Spongia (Heterofibria) sucrensis sp. nov. (Figure 2)

Material type: Holotype. MZUSU-I00005: Boca La Caimanera, breakwater, 1-3 m, August 20, 2017, col. J. David; Paratypes: MZUSU-I00026: Punta Piedra, coral reef, 2-4 m, June 22, 2018, col. J. David; MZUSU-I00027: Boca La Caimanera, breakwater, 1-3 m, August 20, 2017, col. J. David; MZUSU-I00028: Punta Piedra, coral reef, 2-4 m, June 22, 2018, col. J. David.

Additional material for comparison: Spongia (Spongia) tubulifera (MZUSU-I00014); Hyattella cavernosa (MZUSU-I00040); S. (Spongia) anclotea (MZUSU-I00036).

Diagnosis: massive sponge, with erect and creeping lobes or branches. Skeleton of ascending primary fibers cored with foreign material. Meshes of uncored secondary and pseudo-tertiary fibers dominate the skeleton. Lighter pseudo-tertiary fibers are connected to the other types of fibers or forming a reticulum within the meshes of secondary fibers.

External morphology: massive sponge with erect, creeping lobes of a maximum length of $5 \mathrm{~cm}$, and a maximum width of $1.7 \mathrm{~cm}$. Round oscula as perforations of the pinacoderm, 1-3 $\mathrm{mm}$ in diameter, located mainly on the upper part of the lobes and arranged linearly along 
a lo largo de la esponja. Superficie cubierta por cónulos de altura de entre 0,3 y $0,8 \mathrm{~mm}$. Algunos de los cónulos tienen una fibra final emergente muy fina. Consistencia elástica y compresible, difícil de rasgar. Color in situ negro en parte superior y cremoso a blanco en la zona basal e interior de with the sponge. Surface covered by conules of height between 0.3 and $0.8 \mathrm{~mm}$. Some of the conules have a fine fiber protruding from the apices. Elastic and compressible consistency, difficult to tear. Color in situ black in the upper part and creamy to white in the basal and interior

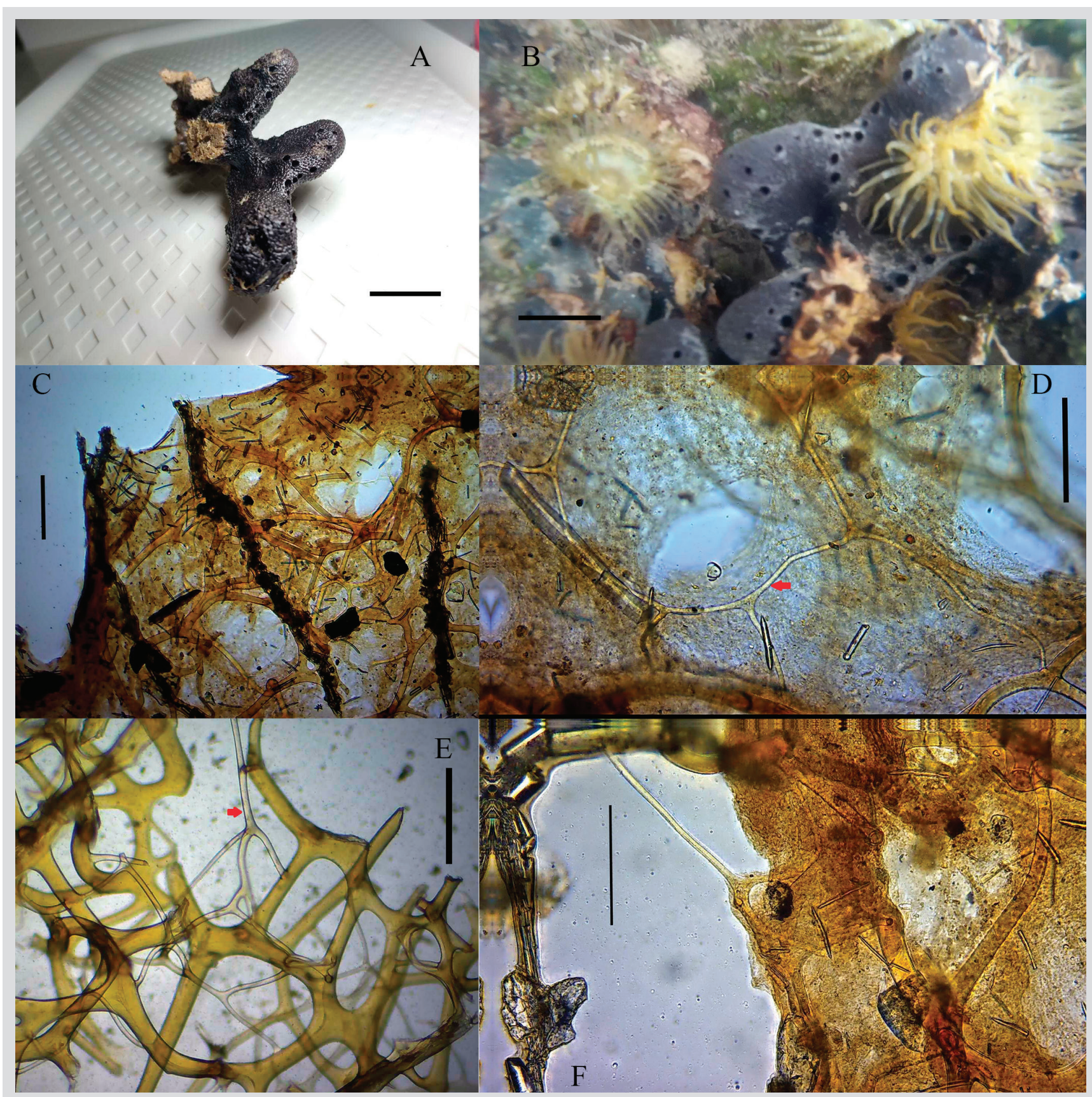

Figura 2. Spongia (Heterofibria) sucrensis sp. nov. A) Espécimen preservado (escala: $3 \mathrm{~cm}$ ). B) Espécimen in situ (escala: $3 \mathrm{~cm}$ ). C) Arquitectura del esqueleto, fibras primarias con inclusiones de material foráneo que emergen hacia la superficie formando un cónulo (escala: $300 \mu \mathrm{m})$. D) Arquitectura del esqueleto con material orgánico, retículo de fibras pseudoterciarias (flecha roja) (escala: $200 \mu \mathrm{m}$ ). E) Arquitectura del esqueleto sin material orgánico, retículo de fibras pseudoterciarias (flecha roja) (escala: $200 \mu \mathrm{m})$. F) Fibra pseudoterciaria solitaria (escala: $200 \mu \mathrm{m}$ ).
Figure 2. Spongia (Heterofibria) sucrensis sp. nov. A) Preserved specimen (scale: $3 \mathrm{~cm}$ ). B) Specimen in situ (scale: $3 \mathrm{~cm}$ ). C) Architecture of the skeleton, primary fibers cored with of foreign material that emerge towards the surface forming a conule (scale: $300 \mu \mathrm{m})$. D) Architecture of the skeleton with organic material, the reticulum of pseudo-tertiary fibers (red arrow) (scale: $200 \mu \mathrm{m}$ ). E) Architecture of the skeleton without organic material, the reticulum of pseudo-tertiary fibers (red arrow) (scale: $200 \mu \mathrm{m}$ ). F) Solitary pseudo-tertiary fiber (scale: $200 \mu \mathrm{m}$ ). 
la esponja; el color se mantiene en alcohol. Dimensiones máximas: 11,5 × 4,7 × 1,9 cm (largo-alto-ancho) (Figura 2A).

Ectosoma: pinacodermo orgánico distinguible.

Coanosoma: esqueleto anisotrópico, poco denso, algunas veces con mucho detrito, de fibras primarias ascendentes con inclusiones de material foráneo (espículas y detritos); muchas de estas fibras se bifurcan en tramos menos gruesos al acercarse a la superficie, donde la distancia entre estas es menor (Figura 2C). Las fibras secundarias y pseudoterciarias sin inclusiones dominan el esqueleto reticulado y están conectadas a otras fibras formando mallas. Las secundarias forman frecuentemente polígonos irregulares en cuanto a tamaño y forma mientras las pseudoterciarias se hallan solas, conectadas con los otros tipos de fibras o formando un retículo solo de estas, pero que conecta con los otros tipos de fibras; esto ocurre frecuentemente cerca de la superficie (Figura 2D, 2F). Este retículo se encuentra dentro de mallas de las otras fibras, paralelo a estas, aunque algunas fibras pueden retorcerse en otra dirección y conectarse con otro grupo de mallas (Figura 2D, 2E). Coloración amarilla de las fibras primarias y secundarias, en pseudoterciarias es más clara. Diámetro de fibras: primarias 48-80,2$119 \mu \mathrm{m}(\mathrm{n}=33)$; secundarias 19-41,3-81 $\mu \mathrm{m}(\mathrm{n}=30)$; pseudoterciarias 7-13,9-24 $\mu \mathrm{m}(\mathrm{n}=30)$. Distancia entre fibras primarias: 204-688-1401 $\mu \mathrm{m}(\mathrm{n}=28)$. Diámetro de los polígonos formados por fibras primarias, secundarias y pseudoterciarias: 72-300-801 $\mu \mathrm{m}(\mathrm{n}=30)$; polígonos del retículo de fibras pseudoterciarias: 60-262-563 $\mu \mathrm{m}(\mathrm{n}=20)$.

Ecología: encontrada en sustrato rocoso artificial (rompeolas) y sobre coral muerto a una profundidad aproximada de 1,5 m. Dentro de una esponja se encontraron dos bivalvos del género Mytilopsis; junto a la esponja se hallaron anémonas del género Exaiptasia.

Distribución: costa de Sucre (Caribe colombiano).

Etimología: el nombre específico se refiere al departamento de Sucre, donde fue recolectada. area of the sponge; the color is kept in alcohol. Maximum dimensions: $11.5 \times 4.7 \times 1.9 \mathrm{~cm}$ (length-height-width) (Figure 2A).

Ectosome: distinguishable organic pinacoderm.

Coanosoma: anisotropic skeleton, not very dense, sometimes with much debris, of ascending primary fibers cored with foreign material (spicules and debris); many of these fibers bifurcate into thinner sections as they approach the surface, where the distance between them is less (Figure 2C). Uncored secondary and pseudotertiary fibers dominate the reticulated skeleton and are connected to other fibers forming meshes. The secondaries are frequently formed irregular polygons in terms of size and shape while the pseudo-tertiary ones are found alone, connected with the other types of fibers or forming a reticulum only of these, but that connects with the other types of fibers; this frequently occurs near the surface (Figure 2D, 2F). This reticulum is found within meshes of the other fibers, parallel to these, although some fibers can twist in another direction and connect with another group of meshes (Figure 2D, 2E). Yellow coloration of the primary and secondary fibers, in pseudo-tertiary is clearer. Fiber diameter: primary 48-80.2-119 $\mu \mathrm{m}(\mathrm{n}=33)$; secondaries 19-41.3-81 $\mu \mathrm{m}(\mathrm{n}=30)$; pseudo-tertiary 7-13.9-24 $\mu \mathrm{m}$ $(\mathrm{n}=30)$. Distance between primary fibers: 204-688-1401 $\mu \mathrm{m}(\mathrm{n}=28)$. Diameter of the polygons formed by primary, secondary and pseudo-tertiary fibers: 72-300-801 $\mu \mathrm{m}$ $(n=30)$; reticulum polygons of pseudo-tertiary fibers: 60 $262-563 \mu \mathrm{m}(\mathrm{n}=20)$.

Ecology: Found in the artificial rocky substrate (breakwater) and on dead coral at a depth of approximately $1.5 \mathrm{~m}$. Inside a sponge, two bivalves of the genus Mytilopsis were found; Anemones of the genus Exaiptasia were found next to the sponge.

Distribution: Sucre coast (Colombian Caribbean).

Etymology: The specific name refers to the department of Sucre, where it was collected. 
Tabla 1. Características diagnósticas de las especies del subgénero Heterofibria. Diámetros de PR: fibras primarias, SC: fibras secundarias, PT: fibras pseudoterciarias.
Table 1. Diagnostic characteristics of the subgenus Heterofibria species. Diameters of PR: Primary fibers, SC: Secondary fibers, PT: Pseudo-tertiary fibers.

\begin{tabular}{|c|c|c|c|c|c|c|}
\hline Especie/ Species & $\begin{array}{c}\text { PR } \\
(\mu \mathrm{m})\end{array}$ & $\begin{array}{c}\mathrm{SC} \\
(\mu \mathrm{m})\end{array}$ & $\begin{array}{l}\text { PT } \\
(\mu \mathrm{m})\end{array}$ & $\begin{array}{c}\text { Retículo de } \\
\text { pseudoterciarias/ Pseudo- } \\
\text { tertiary grid }\end{array}$ & $\begin{array}{l}\text { Forma de crecimiento/ } \\
\text { Growth form }\end{array}$ & Superficie/ Surface \\
\hline $\begin{array}{l}\text { S.(H.) sucrensis sp. } \\
\text { nov. }\end{array}$ & $\begin{array}{c}48-80.2-119 \\
(\mathrm{n}=30)\end{array}$ & $\begin{array}{c}19-41.3-81 \\
(\mathrm{n}=30)\end{array}$ & $\begin{array}{c}7-13.9-24 \\
(\mathrm{n}=30)\end{array}$ & $\begin{array}{l}\text { Conectado dentro de mallas } \\
\text { de otras fibras primarias y } \\
\text { secundarias. Algunas fibras } \\
\text { de este retículo pueden } \\
\text { retorcerse en otra dirección } \\
\text { y conectarse con otro grupo } \\
\text { de mallas/ Connected within } \\
\text { meshes of other primary } \\
\text { and secondary fibers. Some } \\
\text { fibers of this reticulum can } \\
\text { twist in another direction } \\
\text { and connect with another } \\
\text { group of meshes }\end{array}$ & $\begin{array}{l}\text { Masiva con lóbulos } \\
\text { rastreros y erectos/ } \\
\text { Massive with creeping } \\
\text { and erect lobes }\end{array}$ & $\begin{array}{l}\text { Cónulos de } 0.3-0.8 \mathrm{~mm} / \\
\text { Conules of } 0.3-0.8 \mathrm{~mm}\end{array}$ \\
\hline $\begin{array}{l}\text { S. (H.) manipulatus } \\
\text { Cook y Bergquist, } \\
2001\end{array}$ & $\begin{array}{c}35-78-184 \\
(\mathrm{n}=14)\end{array}$ & $\begin{array}{c}24-34-46 \\
(\mathrm{n}=38)\end{array}$ & $\begin{array}{l}4-13-23 \\
(\mathrm{n}=42)\end{array}$ & $\begin{array}{l}\text { El retículo de } \\
\text { pseudoterciarias forma } \\
\text { redes dentro de las mallas } \\
\text { de secundarias y se } \\
\text { extiende a otras mallas/ The } \\
\text { pseudo-tertiary reticulum } \\
\text { forms networks within } \\
\text { the secondary meshes and } \\
\text { extends to other meshes }\end{array}$ & Masiva/ Massive & $\begin{array}{l}\text { Con túbulos cónicos } \\
\text { con ósculos terminales. } \\
\text { Abundantemente conulosa/ } \\
\text { With conical tubules with } \\
\text { terminal oscula. Abundantly } \\
\text { conulous }\end{array}$ \\
\hline $\begin{array}{l}\text { S. (H.) } \\
\text { gorgonocephalus } \\
\text { Cook y Bergquist, } \\
2001\end{array}$ & $\begin{array}{c}38-55-126 \\
(\mathrm{n}=14)\end{array}$ & $\begin{array}{l}12-29-55 \\
(\mathrm{n}=31)\end{array}$ & $\begin{array}{c}4-8-9 \\
(n=15)\end{array}$ & No & $\begin{array}{l}\text { Pequeña, masiva y } \\
\text { compacta/ Small, } \\
\text { massive and compact }\end{array}$ & $\begin{array}{l}\text { Cónulos estrechos, } \\
\text { sobresalen de toda la } \\
\text { esponja, algunos túbulos } \\
\text { osculares. Cónulos con un } \\
\text { "cordón" de fibras, terminal } \\
\text { y emergente/ Narrow } \\
\text { conules protruding from the } \\
\text { entire sponge, some osseous } \\
\text { tubules. Conules with a } \\
\text { terminal, emergent "cord" } \\
\text { of fibers }\end{array}$ \\
\hline $\begin{array}{l}\text { S. (H.) corrugata } \\
\text { Cook y Bergquist, } \\
2001\end{array}$ & $\begin{array}{c}29-58-175 \\
(\mathrm{n}=24)\end{array}$ & $\begin{array}{c}10-21-31 \\
(\mathrm{n}=28)\end{array}$ & $\begin{array}{c}2-5-6 \\
(\mathrm{n}=25)\end{array}$ & $\begin{array}{l}\text { El retículo está más } \\
\text { inclinado a formar redes } \\
\text { en un solo plano dentro } \\
\text { de mallas de secundarias, } \\
\text { aunque puede conectarse } \\
\text { con fibras secundarias } \\
\text { adyacentes/ The reticulum } \\
\text { is more inclined to form } \\
\text { networks in a single } \\
\text { plane within meshes of } \\
\text { secondaries, although it } \\
\text { can connect with adjacent } \\
\text { secondary fibers }\end{array}$ & $\begin{array}{l}\text { Masiva e irregular/ } \\
\text { Massive and irregular }\end{array}$ & $\begin{array}{l}\text { Numerosos espacios } \\
\text { subdermales/ Numerous } \\
\text { subdermal spaces }\end{array}$ \\
\hline $\begin{array}{l}\text { S. (H.) decooki Van } \\
\text { Soest y Hopper, } \\
2020\end{array}$ & $\begin{array}{l}29-49-78 \\
(\mathrm{n}=32)\end{array}$ & $\begin{array}{c}17-30-42 \\
(\mathrm{n}=40)\end{array}$ & $\begin{array}{l}4-10-17 \\
(\mathrm{n}=40)\end{array}$ & $\begin{array}{l}\text { El retículo se encuentra } \\
\text { dentro de mallas de fibras } \\
\text { secundarias/ The reticulum } \\
\text { is found within meshes of } \\
\text { secondary fibers }\end{array}$ & $\begin{array}{l}\text { Incrustante a masiva/ } \\
\text { Encrusting to massive }\end{array}$ & $\begin{array}{l}\text { Con mechones de fibras } \\
\text { emergentes que se unen. } \\
\text { Pinacodermo traslúcido. } \\
\text { Túbulos bajos/ With tufts } \\
\text { of emerging fibers that } \\
\text { come together. Translucent } \\
\text { pinacoderm. Low tubules }\end{array}$ \\
\hline $\begin{array}{l}\text { S. (H.) purpurea } \\
\text { Kim y Sim, } 2009\end{array}$ & $40-103$ & $15-40$ & $3-6$ & No & $\begin{array}{l}\text { Masiva con muchos } \\
\text { lóbulos/ Massive with } \\
\text { many lobes }\end{array}$ & $\begin{array}{l}\text { Porosa, con una membrana } \\
\text { delgada translúcida entre } \\
\text { los lóbulos/ Porous, with a } \\
\text { thin translucent membrane } \\
\text { between the lobes }\end{array}$ \\
\hline
\end{tabular}




\begin{tabular}{|c|c|c|c|c|c|c|}
\hline Especie/ Species & $\begin{array}{c}\mathrm{PR} \\
(\mu \mathrm{m})\end{array}$ & $\begin{array}{c}\mathrm{SC} \\
(\mu \mathrm{m})\end{array}$ & $\begin{array}{c}\text { PT } \\
(\mu \mathrm{m})\end{array}$ & $\begin{array}{c}\text { Retículo de } \\
\text { pseudoterciarias/ Pseudo- } \\
\text { tertiary grid }\end{array}$ & $\begin{array}{l}\text { Forma de crecimiento/ } \\
\text { Growth form }\end{array}$ & Superficie/ Surface \\
\hline $\begin{array}{l}\text { S. }(H .) \text { corallina } \\
\text { Kim y Sim, } 2009\end{array}$ & $40-120$ & $15-50$ & 10 & $\begin{array}{l}\text { Retículo unido a una } \\
\text { membrana superficial/ } \\
\text { Reticulum attached to a } \\
\text { surface membrane }\end{array}$ & Masiva/ Massive & $\begin{array}{l}\text { Una membrana translúcida } \\
\text { cubre la superficie. Lóbulos } \\
\text { verticales con ósculos } \\
\text { terminales/ A translucent } \\
\text { membrane covers the } \\
\text { surface. Vertical lobes with } \\
\text { terminal oscula }\end{array}$ \\
\hline $\begin{array}{l}\text { S. }(H .) \text { peddemorsi } \\
\text { Samaai, Pillay \& } \\
\text { Janson, } 2020\end{array}$ & $55-65-89$ & $23-28-37$ & $12-16-18$ & $\begin{array}{l}\text { Retículo dentro de mallas } \\
\text { poligonales e interconectado } \\
\text { con fibras secundarias } \\
\text { adyacentes/ Reticulum } \\
\text { within polygonal meshes and } \\
\text { interconnected with adjacent } \\
\text { secondary fibers }\end{array}$ & $\begin{array}{l}\text { Masiva, digitada/ } \\
\text { Massive, typed }\end{array}$ & $\begin{array}{l}\text { Superficie lisa con fibras } \\
\text { expuestas/ Smooth surface } \\
\text { with exposed fibers }\end{array}$ \\
\hline $\begin{array}{l}\text { S. (H.) smaragdus } \\
\text { Samaai, Pillay \& } \\
\text { Janson, } 2019\end{array}$ & $32-40-45$ & $16-20-26$ & $\begin{array}{l}\text { No se } \\
\text { menciona/ } \\
\text { Not } \\
\text { mentioned }\end{array}$ & No & $\begin{array}{l}\text { Masiva, amorfa a } \\
\text { densamente incrustante./ } \\
\text { Massive, amorphous to } \\
\text { thickly encrusting }\end{array}$ & $\begin{array}{l}\text { Conulosa con fibras } \\
\text { expuestas y fistulas/ } \\
\text { Conulous with exposed } \\
\text { fibers and fistulas }\end{array}$ \\
\hline $\begin{array}{l}\text { S. (H.) catarinensis } \\
\text { Mothes } \text { et al. } 2006\end{array}$ & $\begin{array}{l}60-69.3-100 \\
(\mathrm{n}=50)\end{array}$ & $\begin{array}{c}11-32.2-69 \\
(\mathrm{n}=50)\end{array}$ & $\begin{array}{l}2,3-13.3-23 \\
(\mathrm{n}=50)\end{array}$ & No & $\begin{array}{l}\text { Masiva, incrustante con } \\
\text { proyecciones irregulares } \\
\text { esparcidas lateralmente/ } \\
\text { Massive, encrusting with } \\
\text { irregular projections } \\
\text { scattered laterally }\end{array}$ & $\begin{array}{l}\text { Cónulos de altura de hasta } \\
2 \mathrm{~mm} \text {, con proyecciones } \\
\text { lobuladas discretas con } \\
\text { ósculos terminales/ Conules } \\
\text { up to } 2 \mathrm{~mm} \text { tall, with } \\
\text { discrete lobed projections } \\
\text { with terminal oscula }\end{array}$ \\
\hline
\end{tabular}

\section{DISCUSIÓN}

Según Van Soest et al. (2019), el género Spongia tiene hasta el momento ocho especies registradas para el Caribe: S. (Spongia) obliqua Duchassaing y Michelotti, 1864, S. (Spongia) barbara Duchassaing y Michelotti, 1864, S. anclotea, S. (Spongia) coelosia Duchassaing y Michelotti, 1864, S. (Spongia) obscura Hyatt, 1877, S. (Spongia) pilosa (Wilson, 1902), S. (Spongia) solitaria Hyatt, 1877 y S. tubulifera. De ellas, S. tubulifera y $S$. anclotea (como $S$. obscura y $S$. pertusa, respectivamente) se han registrado y descrito en diferentes áreas del Caribe colombiano (Zea, 1987). Por lo tanto, con la descripción de S. sucrensis se amplía el registro a nueve especies del género para el Caribe y a tres para Colombia. De igual forma, es la primera vez que se registra el subgénero Heterofibria en el Caribe. Anteriormente, el subgénero solo se había registrado en Suramérica en la Ilha das Aranhas en el estado de Santa Catarina (Brasil) (Mothes et al., 2006; Muricy et al., 2011), en Nueva Zelanda (Cook y Bergquist, 2001), en Corea (Kim y Sim, 2009) y en la costa oriental de Sudáfrica (Samaai et al., 2019).

Esta nueva especie es cercana a Spongia (Heterofibria) catarinensis (Mothes et al., 2006), pero

\section{DISCUSSION}

According to Van Soest et al. (2019), the genus Spongia has so far eight species registered for the Caribbean: S. (Spongia) obliqua Duchassaing and Michelotti, 1864, S. (Spongia) barbara Duchassaing and Michelotti, 1864, S. anclotea, S. (Spongia) coelosia Duchassaing and Michelotti, 1864, S. (Spongia) obscura Hyatt, 1877, S. (Spongia) pilosa (Wilson, 1902), S. (Spongia) solitaria Hyatt, 1877 and S. tubulifera. Of these, S. tubulifera and $S$. anclotea (as $S$. obscura and $S$. pertusa, respectively) have been recorded and described in different areas of the Colombian Caribbean (Zea, 1987). Therefore, with the description of S. sucrensis the record is extended to nine species of the genus for the Caribbean and three for Colombia. Similarly, it is the first time that the subgenus Heterofibria has been recorded in the Caribbean. Previously, the subgenus had only been recorded in South America on the Ilha das Aranhas in the state of Santa Catarina (Brazil) (Mothes et al., 2006; Muricy et al., 2011), in New Zealand (Cook and Bergquist, 2001), in Korea (Kim and Sim, 2009) and on the east coast of South Africa (Samaai et al., 2019).

This new species is close to Spongia (Heterofibria) catarinensis (Mothes et al., 2006), but its 
su morfología externa se diferencia de esta en que las proyecciones esparcidas lateralmente están elevadas; no presenta ósculos ubicados en proyecciones lobadas discretas, elevadas de su superficie; los microcónulos son más pequeños (0,3-0,8 mm); el diámetro máximo de los ósculos es mayor (3 $\mathrm{mm}$ por $2 \mathrm{~mm}$ en $S$. catarinensis) y no hay una membrana translúcida circundando la abertura de estos. En cuanto al esqueleto, cerca de la superficie la nueva especie posee retículos formados por fibras pseudoterciarias que conectan con las primarias y secundarias adyacentes. Estos retículos están ausentes en $S$. catarinensis. Las mediciones realizadas muestran que el diámetro máximo de las fibras primarias y secundarias es mayor en la especie nueva mientras que las fibras pseudoterciarias presentan gran similitud (Tabla 1). El retículo de fibras pseudoterciarias ha sido mencionado también en otras especies del subgénero que tienen una distribución alejada con respecto a la nueva especie. Debido a la corta duración de las larvas de esponjas, es muy poco probable que se trate de ellas (Klautau et al., 1999). Spongia (H.) peddemorsi [igual a S. cooki en Samaai et al. (2019)], una especie de Sudáfrica, también posee un retículo de fibras pseudoterciarias conectado con fibras secundarias, pero discrepa de la nueva especie en la presencia de una capa superficial de colágeno y en menores diámetros de fibras (primarias, 55-65-89 $\mu \mathrm{m}$; secundarias, 23-28-37 $\mu \mathrm{m}$ ) (Tabla 1). De igual forma, la especie nueva se diferencia de $S$. (H.) corallina y $S$. (H.) purpurea en que las fibras peudoterciarias de estas se encuentran conectadas a una membrana dermal y no a fibras primarias o secundarias (Kim y Sim, 2009). Con respecto a las especies de Nueva Zelanda presentadas en Cook y Bergquist (2001), la nueva especie es semejante en la arquitectura del esqueleto a $S$. (H.) decooki [misma que $S$. (H.) cristata] y $S$. (H.) mokohinau, pero en la morfología externa se diferencia consistentemente. La morfología externa es un carácter que puede variar en algunas especies de esponjas dependiendo del hábitat; sin embargo, en este caso, la morfología ha sido utilizada para diferenciar las especies de este subgénero (Cook y Bergquist, 2001; Samai et al., 2019). En el presente trabajo, se utiliza la forma de los ósculos de la especie nueva como un carácter diferenciador, dado que, tanto en el holotipo como en los paratipos, a pesar de ser de distintos hábitats, los ósculos se encuentran como perforaciones de la dermis, por lo que parece ser un carácter consistente.

Esta especie se diferencia de S. tubulifera $y$ $S$. anclotea, que también se encuentran en el Caribe colombiano, principalmente por la presencia de fibras pseudoterciarias. Así mismo, sus fibras son de mayor external morphology differs from this in that the laterally scattered projections are elevated; it does not feature oscula located in discrete raised lobed projections of its surface; the microconules are smaller $(0.3-0.8 \mathrm{~mm})$; the maximum diameter of the oscula is greater $(3 \mathrm{~mm}$ by $2 \mathrm{~mm}$ in $S$. catarinensis) and there is no translucent membrane surrounding the opening of the oscula. Regarding the skeleton, near the surface, the new species has reticles formed by pseudo-tertiary fibers that connect with the adjacent primary and secondary fibers. These reticles are absent in $S$. catarinensis. The measurements carried out show that the maximum diameter of the primary and secondary fibers is greater in the new species, while the pseudo-tertiary fibers show great similarity (Table 1). The reticulum of pseudo-tertiary fibers has also been mentioned in other species of the subgenus that have a distant distribution with respect to the new species. Due to the short duration of sponge larvae, it is highly unlikely that they are (Klautau et al., 1999). Spongia (H.) peddemorsi [equal to S. cooki in Samaai et al. (2019)], a species from South Africa, also possesses a reticulum of pseudo-tertiary fibers connected with secondary fibers, but it differs from the new species in the presence of a superficial collagen layer and smaller fiber diameters (primary, 55-65-89 $\mu \mathrm{m}$, secondary 23-28-37 $\mu \mathrm{m}$ ) (Table 1). In the same way, the new species differs from $S$. (H.) corallina and $S$. (H.) purpurea in that their peudo-tertiary fibers are connected to a dermal membrane and not to primary or secondary fibers (Kim and Sim, 2009). For the New Zealand species presented in Cook and Bergquist (2001), the new species is similar in skeletal architecture to $S$. (H.) decooki [same as $S$. (H.) cristata] and $S$. (H.) mokohinau, but in external morphology, it differs consistently. The external morphology is a character that can vary in some species of sponges depending on the habitat. However, in this case, morphology has been used to differentiate the species of this subgenus (Cook and Bergquist, 2001; Samai et al., 2019). In the present work, the shape of the oscula of the new species is used as a differentiating character, since, both in the holotype and in the paratypes, despite being from different habitats, the oscula as perforations of the dermis, so it seems to be a consistent character.

This species differs from $S$. tubulifera and S. anclotea, which are also found in the Colombian Caribbean, mainly due to the presence of pseudo-tertiary fibers. Likewise, its fibers are larger in diameter and more irregular in architecture than in S. tubulifera and its external morphology does not present the oscular tubules 
diámetro y de arquitectura más irregular que en $S$. tubulifera y su morfología externa no presenta los túbulos osculares característicos de esta. Spongia anclotea, además de presentar fibras de menor diámetro, las tiene muy condensadas, por lo que se llegan a distinguir solo las fibras primarias por las inclusiones de material foráneo. Por último, aunque $H$. cavernosa posee fibras de diámetro pequeño que podrían denominarse como pseudoterciarias, estas son de mayor diámetro que las de la nueva especie. Las fibras primarias están a mayor distancia entre ellas y se encuentran, a menudo, libres de inclusiones. También, $H$. cavernosa posee espacios subdermales profundos que están ausentes en la nueva especie.

\section{AGRADECIMIENTOS}

Al profesor Sven Zea (Universidad Nacional de Colombia sede Caribe) por su enseñanza en la taxonomía de esponjas, al estudiante Farid Paternina por su ayuda en el trabajo de laboratorio, a los estudiantes Juan Tovar y Erwin Sequeda por su ayuda en el trabajo de campo y a la Escuela de Infantería de Marina de Colombia por permitir la realización de algunas salidas de campo. characteristic of this. Spongia anclotea, in addition to having smaller diameter fibers, is highly condensed, so that only the primary fibers can be distinguished by cored of foreign material. Finally, although $H$. cavernosa has small diameter fibers that could be called pseudo-tertiary, these are larger in diameter than those of the new species. The primary fibers are at a greater distance from each other and are often uncored. Also, H. cavernosa has deep subdermal spaces that are absent in the new species.

\section{ACKNOWLEDGEMENT}

Special thanks to Professor Sven Zea (Universidad Nacional de Colombia, Caribbean headquarters) for his teaching on sponge taxonomy, to the student Farid Paternina for his help in the laboratory work, to the students Juan Tovar and Erwin Sequeda for their help in the fieldwork, and to the Colombian Marine Infantry School for allowing some field trips to be carried out.

\section{BIBLIOGRAFÍA/LITERATURE CITED}

Cook, S. and P.R. Bergquist. 2001. New species of Spongia (Porifera: Demospongiae: Dictyoceratida) from New Zealand, and a proposed subgeneric structure. N. Z. J. Mar. Freshwater Res., 35: 33-58. https://doi.org/10.1080/00288330.2001. 9516977

Cook, S. and P.R. Bergquist. 2002. Family Spongiidae: 1051-1060. In: Hooper, J. and R. Van Soest (Eds.). Systema Porifera: A Guide to the Classification of Sponges. Kluwer Academic/Plenum Publishers, New York. 1763 p.

De Laubenfels, M.W. and J.F. Storr. 1958. The taxonomy of American commercial sponges. Bull. Mar. Sci. Gulf Carib., 8(2): 99-117.

Duchassaing de Fonbressin, P. and G. Michelotti. 1864. Spongiaires de la mer Caraibe. Natuurkundige verhandelingen van de Hollandsche maatschappij der wetenschappen te Haarlem, 21(2): 1-124.

Ellis, J. and D. Solander. 1786. The natural history of many curious and uncommon zoophytes, collected from various parts of the globe. Systematically arranged and described. Benjamin White \& Son, London. 206 p.

Gray, J.E. 1867. Notes on the arrangement of sponges, with the descriptions of some new genera. Proc. Zool. Soc. London, 1867(2): 492-558.

Hooper, J.N. and R.W. Van Soest. 2002. Systema Porifera. A guide to the classification of sponges. Springer US, Boston. $1708 \mathrm{p}$.

Hyatt, A. 1877. Revision of the North American Poriferae; with remarks upon foreign species. Part II. Mem. Boston Soc. Nat. Hist., 2: 481-554.

Kim, H.R. and C.J. Sim. 2009. Two new Spongia species (Dictyoceratida: Spongiidae) from Korea. Anim. Cells. Syst, 13(2): 141-145. https://doi.org/10.1080/19768354.2009.9647205 
Klautau, M., C.A. Russo, C. Lazoski, N. Boury-Esnault, J.P. Thorpe, and A.M. Solé-Cava. 1999. Does cosmopolitanism result from overconservative systematics? A case study using the marine sponge Chondrilla nucula. Evolution, 53(5): 1414-1422. https://doi.org/10.1111/j.1558-5646.1999.tb05406.x.

Lamarck, J.B. 1813-1814. Sur les polypiers empâtés. Ann. Mus. Nat. Hist. nat., 20: 294-312; 370-386; 432-458.

Lamarck, J.B. 1816. Histoire naturelle des animaux sans vertèbres. Tome second. Verdière, Libraire, Paris. 568 p.

Linnaeus, C. 1759. Systema naturae per regna tria naturae, secundum classes, ordines, genera, species, cum characteribus, differentiis, synonymis, locis. Tomus II. Edición décima reformada. Holmiae: impensis direct. Laurentii Salvii. 1384 p.

Minchin, E.A. 1900. Chapter III. Sponges. 1-178. In: Lankester, E.R. (Ed.). A treatise on zoology. Part II. The Porifera and Coelenterata. 2. Adam \& Charles Black, London. 178 p.

Mothes, B., G.L. Kasper, C. Lerner, M. Campos y J.L. Carraro. 2006. Spongia (Heterofibria) catarinensis sp. nov. (Porifera, Spongiidae) no litoral de Santa Catarina, Brasil. Iheringia Ser. Zool., 96(3): 335-338. https://doi.org/10.1590/S007347212006000300010

Muricy, G., D. Lopes, E. Hajdu, M. Carvalho, F. Moraes, M. Klautau, C. Menegola, and U. Pinheiro. 2011. Catalogue of Brazilian Porifera, Museu Nacional do Rio de Janeiro, Río de Janeiro. 299 p.

Otero, L., J.C. Ortiz-Royero, J.K. Ruiz-Merchán, A.E. Higgins, and S.A. Henríquez. 2016. Storms or cold fronts: what is really responsible for the extreme waves regime in the Colombian Caribbean coastal region? Nat. Haz. Earth Syst. Sci., 16(2): 391-401. https://doi.org/10.5194/nhess-16-391-2016

Pallas, P.S. 1766. Elenchus zoophytorum sistens generum adumbrationes generaliores et specierum cognitarum succintas descriptiones, cum selectis auctorum synonymis. Fransiscum Varrentrapp, Hagae. 451 p.

Samaai, T., R. Pillay, and L. Janson. 2019. Shallow-water Demospongiae (Porifera) from Sodwana Bay, iSimangaliso Wetland Park, South Africa. Zootaxa, 4587(1): 1-85. https://doi.org/10.11646/zootaxa.4587.1.1

Samaai, T., R. Pillay, and L. Janson. 2020. Suggestion of Spongia (Heterofibria) peddemorsi as replacement name for Spongia (Heterofibria) cooki Samaai, Pillay \& Janson, 2019. Zootaxa, 4728(1): 149-149. https://doi.org/10.11646/ zootaxa.4728.1.9

Sollas, W.J. 1885. A classification of the sponges. Ann. Mag. Nat. Hist., 16(95): 395-395.

Van Soest, R., N. Boury-Esnault, J.N. Hooper, K. Rützler, N.J. de Voogd, J. Álvarez de Glasby, E. Hajdu, A. Pisera, R. Manconi, C. Schoenberg, D. Janussen, K. Tabachnick, M. Klautau, B. Picton, M. Kelly, J. Vacelet, M. Dohrmann, M. Díaz, P. Cárdenas, and J. Carballo. 2019. World Porifera database, Spongia Linnaeus, 1759. http://www.marinespecies. org/porifera/porifera.php? $\mathrm{p}=$ taxdetails\&id=131759. 24/04/2018.

Van Soest, R., J.N. Hooper, and P.J. Butler. 2020. Every sponge its own name: removing Porifera homonyms. Zootaxa, 4745(1): 1-93. https://doi.org/10.11646/zootaxa.4745.1.1

Wilson, H.V. 1900-1902. The sponges collected in Porto Rico in 1899 by the U.S. Fish Commission Steamer Fish Hawk. Bull. U. S. Fish Com., 2: 375-411.

Zea, S. 1987. Esponjas del Caribe colombiano. Catálogo Científico, Bogotá. 286 p. 